\title{
Quantitative trait analysis of the development of pulmonary tolerance to inhaled zinc oxide in mice Scott C Wesselkamper ${ }^{1}$, Lung Chi Chen ${ }^{2}$ and Terry Gordon*2
}

Address: ${ }^{1}$ Department of Environmental Health, University of Cincinnati Medical Center, Cincinnati, OH 45267, USA and ${ }^{2}$ Department of Environmental Medicine, New York University School of Medicine, Tuxedo, NY 10987, USA

Email: Scott C Wesselkamper - scott.wesselkamper@uc.edu; Lung Chi Chen - chenl@env.med.nyu.edu; Terry Gordon* - gordont@env.med.nyu.edu

* Corresponding author

Published: 18 July 2005

Respiratory Research 2005, 6:73 doi:10.1 186/1465-992I-6-73
Received: 16 March 2005

Accepted: 18 July 2005

This article is available from: http://respiratory-research.com/content/6/1/73

(C) 2005 Wesselkamper et al; licensee BioMed Central Ltd.

This is an Open Access article distributed under the terms of the Creative Commons Attribution License (http://creativecommons.org/licenses/by/2.0), which permits unrestricted use, distribution, and reproduction in any medium, provided the original work is properly cited.

\begin{abstract}
Background: Individuals may develop tolerance to the induction of adverse pulmonary effects following repeated exposures to inhaled toxicants. Previously, we demonstrated that genetic background plays an important role in the development of pulmonary tolerance to inhaled zinc oxide $(\mathrm{ZnO})$ in inbred mouse strains, as assessed by polymorphonuclear leukocytes (PMNs), macrophages, and total protein in bronchoalveolar lavage (BAL) phenotypes. The BALB/cByJ (CBy) and DBA/2J (D2) strains were identified as tolerant and non-tolerant, respectively. The present study was designed to identify candidate genes that control the development of pulmonary tolerance to inhaled $\mathrm{ZnO}$.
\end{abstract}

Methods: Genome-wide linkage analyses were performed on a CByD2F2 mouse cohort phenotyped for BAL protein, PMNs, and macrophages following 5 consecutive days of exposure to $1.0 \mathrm{mg} / \mathrm{m}^{3}$ inhaled $\mathrm{ZnO}$ for 3 hours/day. A haplotype analysis was carried out to determine the contribution of each quantitative trait locus (QTL) and QTL combination to the overall BAL protein phenotype. Candidate genes were identified within each QTL interval using the positional candidate gene approach.

Results: A significant quantitative trait locus (QTL) on chromosome I, as well as suggestive QTLs on chromosomes 4 and 5, for the BAL protein phenotype, was established. Suggestive QTLs for the BAL PMN and macrophage phenotypes were also identified on chromosomes I and 5, respectively. Analysis of specific haplotypes supports the combined effect of three QTLs in the overall protein phenotype. Toll-like receptor 5 (T/r5) was identified as an interesting candidate gene within the significant QTL for BAL protein on chromosome I. Wild-derived TIr5-mutant MOLF/Ei mice were tolerant to $\mathrm{BAL}$ protein following repeated $\mathrm{ZnO}$ exposure.

Conclusion: Genetic background is an important influence in the acquisition of pulmonary tolerance to BAL protein, PMNs, and macrophages following $\mathrm{ZnO}$ exposure. Promising candidate genes exist within the identified QTL intervals that would be good targets for additional studies, including TIr5. The implications of tolerance to health risks in humans are numerous, and this study furthers the understanding of gene-environment interactions that are likely to be important factors from person-to-person in regulating the development of pulmonary tolerance to inhaled toxicants. 


\section{Introduction}

Individuals may develop tolerance to adverse health effects elicited from repeated exposure to inhaled toxicants in several different occupational and environmental situations. Pulmonary tolerance can be defined as the lung's ability to withstand the detrimental effects of a toxic compound following multiple exposures. There are several implications of tolerance to human health, having both advantages and disadvantages with respect to the development of harmful health effects. Clinical investigations of zinc oxide ( $\mathrm{ZnO}$ )- [1], endotoxin- [2], and ozone[3-6] induced adverse respiratory effects have demonstrated inter-individual variability in the capacity to develop pulmonary tolerance following inhalation exposure. Because these clinical studies are more tightly controlled than epidemiologic studies, they suggest that genetic background and gene-environment interactions contribute to the development of pulmonary tolerance in humans.

We initially characterized the pulmonary tolerance phenotype in an outbred mouse model by assessing levels of BAL protein and polymorphonuclear leukocytes (PMNs) following single (1X) and 5 daily repeated (5X) exposures to inhaled $\mathrm{ZnO}$ to begin the identification of the genes regulating the development of pulmonary tolerance to repeated toxicant exposure [7]. Significant genetic variability in the development of pulmonary tolerance to $\mathrm{ZnO}$, endotoxin, and ozone was established in several inbred strains of mice in a subsequent study [8]. Of the strains tested, the BALB/CByJ (CBy) strain was tolerant and the DBA/2J (D2) strain was non-tolerant to BAL protein, PMNs, and macrophages following repeated $\mathrm{ZnO}$ exposure.

Because inbred mouse strains are virtually identical at all loci throughout their genome, and also share several chromosomal regions of conserved synteny with humans, they are an ideal animal model in which to investigate genotype-environment interactions and identify genes controlling pulmonary responses to inhaled toxicants where no $a$ priori evidence for their location exists [9]. Inbred strains of mice have been successfully utilized in quantitative trait locus (QTL) analyses to identify candidate genes that control susceptibility to adverse pulmonary responses induced by a variety of inhaled gases [10-13] and particulates $[14,15]$. In the present study, a CByD2F2 mouse cohort was used to determine QTLs linked to the development of pulmonary tolerance to BAL protein, PMN, and macrophage phenotypes following repeated $\mathrm{ZnO}$ exposure.

\section{Materials and methods \\ Mice}

Inbred BALB/CByJ (CBy), DBA/2J (D2) and CByD2F1/J (F1) mice (6-7 weeks of age) were purchased from The Jackson Laboratory (Bar Harbor, ME). CByD2F1/J mice were crossed to produce F2 (intercross) offspring in our laboratory animal facility. All mice were acclimated for at least 1 week before exposure, housed in a positive pressure environment with a 12-hour light/dark cycle starting at 6:00 a.m., and provided with water and standard laboratory rodent chow (Purina, Indianapolis, IN) ad libitum except during exposure. All mice were handled in accordance with the standards established by the U.S. Animal Welfare Acts set forth in National Institutes of Health guidelines, and by the New York University School of Medicine Division of Laboratory Animal Resources.

\section{Zinc oxide generation, characterization, and exposure}

Mice were exposed to $\mathrm{ZnO}\left(1.0 \pm 0.2 \mathrm{mg} / \mathrm{m}^{3}\right.$, mean $\left.\pm \mathrm{SD}\right)$ in stainless steel cages placed inside a $0.07 \mathrm{~m}^{3}$ Plexiglas chamber. $\mathrm{ZnO}$ fumes were generated in a furnace as previously described $[7,16]$. The $\mathrm{ZnO}$ particles had a mass median aerodynamic diameter of $0.3 \mu \mathrm{m}$ and geometric standard deviation of 1.5. Samples of the chamber atmosphere were collected approximately every 40 minutes from the manifold of the exposure system with polytetrafluoroethylene filters (Type TX40HI20-WW, Pallflex Products Corp., Putnam, CT), and the ZnO concentration was determined gravimetrically using a microbalance (Model C-30, Cahn Instruments, Cerritos, CA).

For linkage analyses, all F2 offspring ( $n=299,138$ males and 161 females) were exposed at 7-12 weeks of age in a total of seven 5X exposure regimens. Development of pulmonary tolerance was assessed 24 hours after the fifth exposure, and exposure group sizes ranged from 36 to 45 animals. All $\mathrm{ZnO}$ exposures of $\mathrm{F} 2$ mice also contained at least two CBy, D2, and F1 mice for control purposes.

\section{Bronchoalveolar lavage (BAL)}

Mice were euthanized by intraperitoneal injections of ketamine $\mathrm{HCl}(100 \mathrm{mg} / \mathrm{kg}$, Vetalar, Fort Dodge Laboratories, Inc., Fort Dodge, IA) and sodium pentobarbital (175 mg/ $\mathrm{kg}$, Sleepaway, Fort Dodge Laboratories, Inc.), and the posterior abdominal aorta was severed. The lungs of each mouse were lavaged two times with $1.2 \mathrm{ml}$ of Dulbecco's phosphate buffered saline without $\mathrm{Ca}^{2+}$ or $\mathrm{Mg}^{2+}(\mathrm{pH} 7.2-$ $7.4,37^{\circ} \mathrm{C}$, Invitrogen, Carlsbad, CA). The collected BAL was immediately placed on ice $\left(4^{\circ} \mathrm{C}\right)$ following recovery. Measurement of BAL protein, total cell counts, and differential cell counts were performed as previously described [8]. 


\section{DNA isolation and genotyping}

Genomic DNA was isolated from kidney tissue of each phenotyped F2 animal and for CBy, D2, and F1 controls (Wizard Genomic DNA Purification Kit, Promega, Madison, WI). DNA concentration was determined using a Beckman DU-650 spectrophotometer, and each sample was diluted to $10 \mathrm{ng} / \mu \mathrm{l}$ for genotype analysis. PCRs were performed to genotype F2 offspring for SSLPs located throughout the mouse genome. Eighty-six unlabeled primer pairs for SSLPs that differed in length by at least $5 \%$ between the CBy and D2 progenitor strains were purchased from Research Genetics (ResGen/Invitrogen). PCR was performed in $20 \mu \mathrm{l}$ reaction volumes in 96-well low profile plates (Fisherbrand, Fisher Scientific, Fairlawn, NJ) using a PTC-100 thermal cycler (MJ Research, Watertown, $\mathrm{MA})$. The final concentration for each reaction was: 10 $\mathrm{mM}$ Tris-HCl (pH 8.3), $50 \mathrm{mM} \mathrm{KCL}, 2.5 \mathrm{mM} \mathrm{MgCl}_{2}, 0.2$ $\mathrm{mM}$ of each deoxynucleotide triphosphate (Promega), 1.1X Rediload (ResGen/Invitrogen), and $0.132 \mu \mathrm{M}$ of each SSLP primer pair. This reaction mixture was added to $100 \mathrm{ng}$ of genomic DNA and $0.45 \mathrm{U}$ of Taq DNA polymerase (Roche Applied Science, Indianapolis, IN). Final reaction mixtures were initially denatured at $94^{\circ} \mathrm{C}$ for $3 \mathrm{~min}$, followed by 36 amplification cycles $\left(94^{\circ} \mathrm{C}\right.$ for 30 seconds, $57^{\circ} \mathrm{C}$ for 45 seconds, and $72^{\circ} \mathrm{C}$ for 30 seconds +1 second/cycle). A final extension step at $72^{\circ} \mathrm{C}$ for 7 min was followed by refrigeration $\left(4^{\circ} \mathrm{C}\right)$. PCR products were differentiated on 3\% agarose (Invitrogen) gels and all samples were visualized by ethidium bromide staining using a Chemilmager-4400 low light imaging system (Imgen Technologies, Alexandria, VA) and called by a single investigator. Any questionable calls in reading the genotype from the image were reviewed by a second investigator and if not resolved, that sample was rerun.

\section{Estimation of loci}

The number of independently segregating loci was calculated using the following formula by Wright [17]: $n=(\mathrm{P} 2$ - F1 $)^{2} / 4\left(\left|\sigma_{\mathrm{F} 2}^{2}-\sigma_{\mathrm{F} 1}^{2}\right|\right)$, where $n$ is an estimate of the number of independent loci; P2 and F1 are the mean BAL protein responses following $5 \mathrm{X} \mathrm{ZnO}$ exposure in $\mathrm{CBy}$ and CByD2F1 mice, respectively; $\sigma_{\mathrm{F} 2}^{2}$ and $\sigma_{\mathrm{F} 1}^{2}$ are the computed variances of the F2 and CByD2F1 mice, respectively.

\section{Linkage analyses}

A genome scan was performed to identify associations between genotypes and the BAL protein phenotype using a CByD2F2 mouse cohort. All phenotypic data were natural log normalized to generate a normal distribution to meet normality assumptions of the Map Manager QT computer program. Interval analyses were then performed by fitting a regression equation for the effect of a theoretical QTL at the position of each SSLP and at 1-centimorgan (cM) intervals between SSLPs using free, additive, recessive, and dominant regression models. The regres- sions and significance of each genotype/phenotype association (or likelihood $\chi^{2}$ statistic) were calculated by Map Manager [18]. Permutation tests were performed on the phenotypic and genotypic data using Map Manager to generate empirical thresholds for significance following the methods of Churchill and Doerge $[19,20]$.

For the initial genome scan, the 15 most tolerant and 15 most non-tolerant F2 animals with respect to BAL protein, PMNs, and macrophages (i.e., the phenotypic extremes) were used for selective genotyping [9,21]. Interval analyses were done as stated previously, and 10,000 permutations were performed to generate significant and suggestive likelihood $\chi^{2}$ statistic thresholds for the BAL protein phenotype. Following the identification of a suggestive QTL for BAL protein on chromosome 1, the entire F2 cohort was examined for additional QTLs. For the BAL protein phenotype, three additional SSLPs on chromosome 1 were analyzed, and a permutation test $(10,000$ permutations) was performed with only chromosome 1 . This method was similar to that used in previous linkage studies with inhaled particles and gases that utilized Map Manager QT $[10,14,22]$. All likelihood $\chi^{2}$ statistic thresholds corresponded to those reported in the aforementioned linkage studies.

\section{Haplotype analysis}

A haplotype analysis was carried out similar to that done previously by Prows and Leikauf to determine the contribution of each QTL and QTL combination to the overall BAL protein phenotype [15]. This method quantifies any difference in mean BAL protein levels that are linked with a particular haplotype. Haplotypes for the following SSLPs were used for this analysis: D1Mit291 (101.5 cM), D4Mit254 (82.5 cM), and D5Mit193 (1.0 cM). Mean BAL protein concentrations for groups of F2 mice with the same haplotype at each QTL or QTL combinations were calculated and compared with the mean BAL protein of F2 mice with the other haplotypes to determine the contributions of these QTLs to the overall BAL protein phenotype.

\section{Results \\ Phenotypes of the CByD2F2 cohort}

To further understand the role of genetic background in the development of pulmonary tolerance, an F2 (backcross) cohort derived from the CBy and D2 progenitors was phenotyped. The frequency distribution of the BAL protein, PMN, and macrophage phenotypic responses of the F2 cohort were within the ranges of similarly exposed CBy and D2 progenitor mice (Figure 1).

\section{Selective genotyping}

A genome-wide scan was performed using the 15 most tolerant and 15 most non-tolerant mice to initially identify possible QTLs influencing the development of 


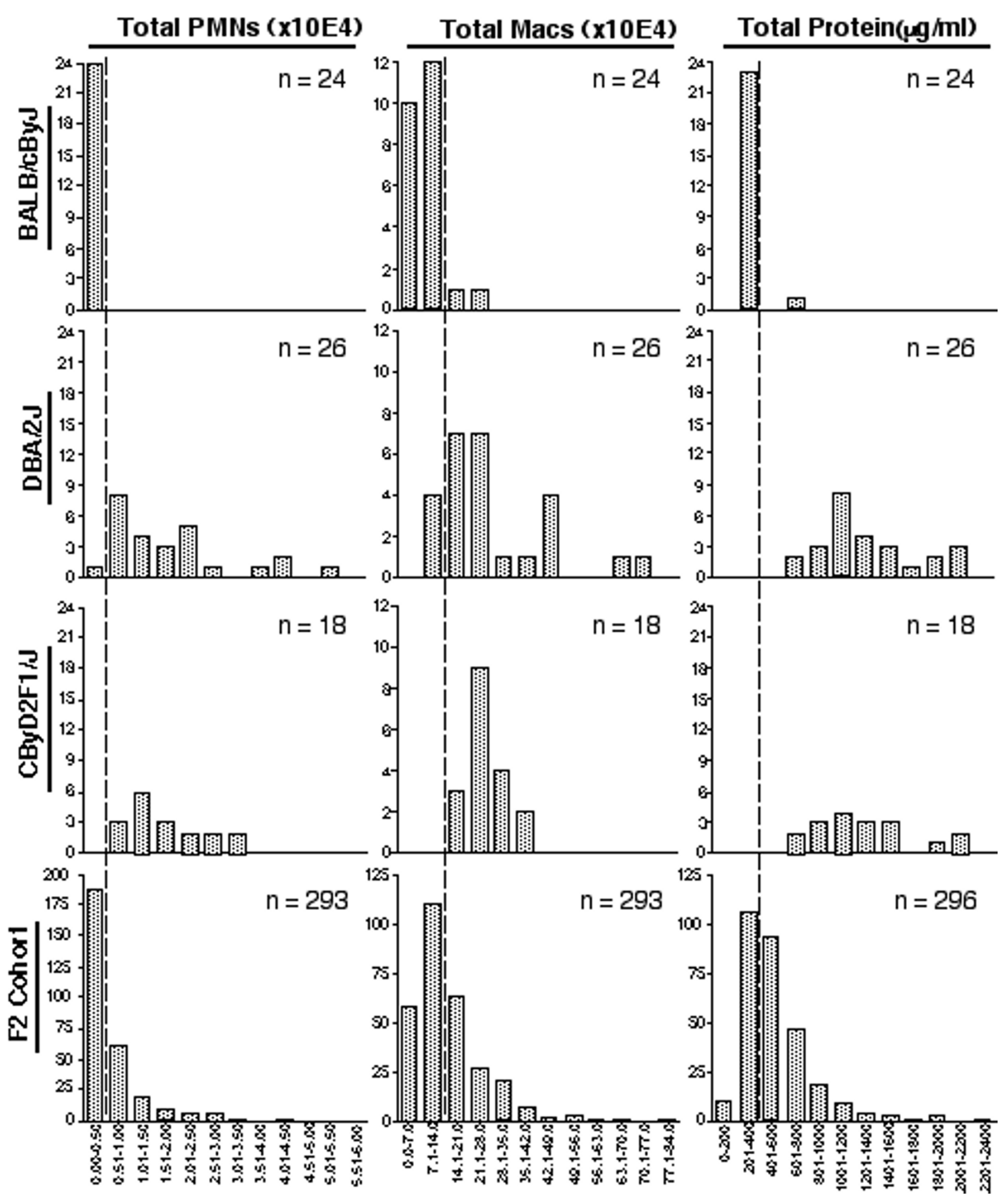

Figure I

Frequency distribution of the number of BAL PMNs $\left(\times 10^{4}\right)$, macrophages $\left(\times 10^{4}\right)$, and protein $(\mu g / \mathrm{ml})$ in BALB/cByJ, DBA/2J, CByD2FI/J, and CByD2F2 mice following 5 consecutive days of exposure to $1.0 \mathrm{mg} / \mathrm{m}^{3} \mathrm{ZnO}$ for $3 \mathrm{~h} /$ day. Vertical dashed lines represent approximate separation points between BALB/cByJ and DBA/2J phenotypes. 

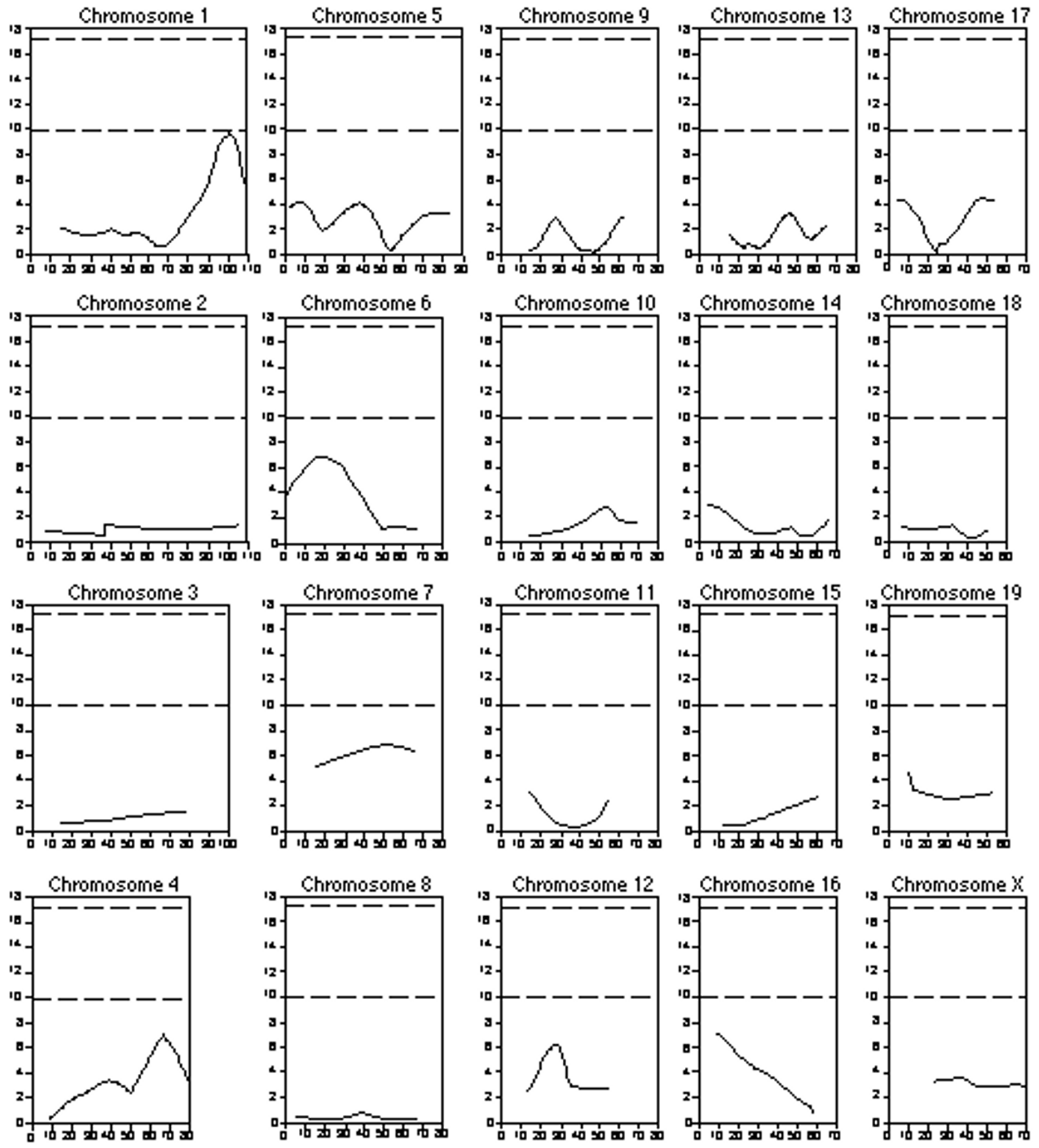

\section{Figure 2}

Genome-wide scan for QTLs associated with the BAL protein phenotype by selective genotyping of the CByD2F2 cohort. For each plot, the $x$-axis is the length of the chromosome in centimorgans (cM), and the $y$-axis is the likelihood $\chi^{2}$ statistic value as calculated by Map Manager. The upper and lower dashed lines represent significant (LRS = 17.4) and suggestive $($ LRS $=9.9)$ linkage thresholds, respectively. 


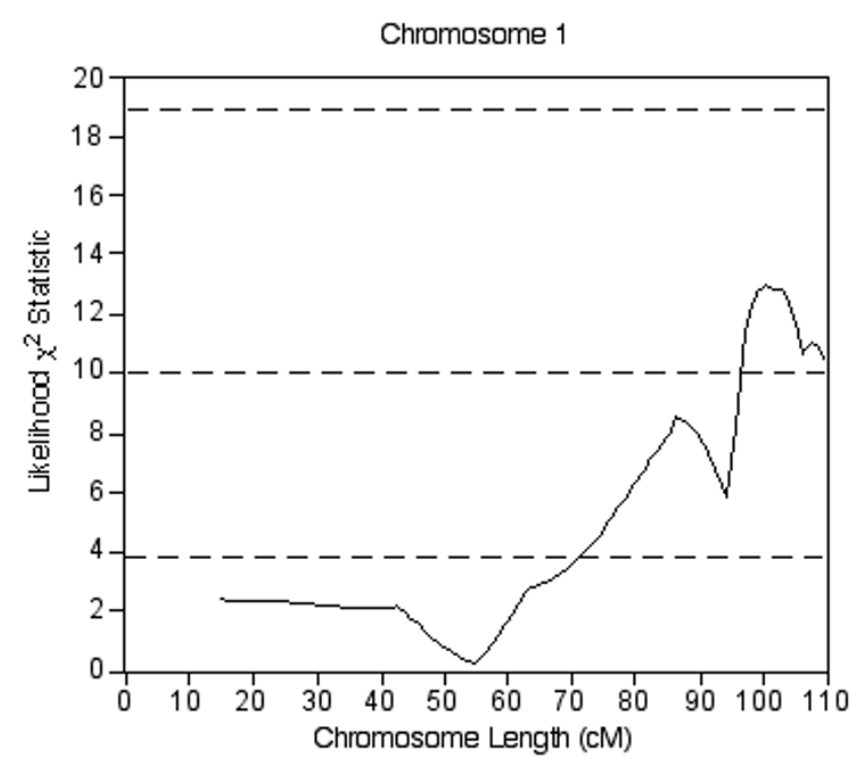

Figure 3

Plot of a significant QTL on chromosome I that is associated with the BAL protein phenotype from analysis of the entire CByD2F2 cohort. The $x$-axis is the length of the chromosome in centimorgans (cM), and the $y$-axis is the likelihood $\chi^{2}$ statistic value as calculated by Map Manager. The lower dashed line represents the suggestive linkage threshold (LRS $=3.8$ ), the middle dashed line represents significant linkage threshold $(\mathrm{LRS}=10.0)$, and the upper dashed line represents the highly significant linkage threshold (LRS = 18.8).

pulmonary tolerance. Permutation tests on the BAL protein-extreme data set established a suggestive likelihood $\chi^{2}$ statistic threshold of 9.9 and a significant likelihood $\chi^{2}$ statistic threshold of 17.4. These values were consistent with the genome-wide probabilities projected by Lander and Kruglyak [23]. Interval mapping identified a suggestive QTL for the BAL protein phenotype on the distal end of chromosome 1 (Figure 2). No QTLs were identified for the PMN and macrophage phenotypes from selective genotyping.

\section{Genotyping of the entire F2 cohort}

The entire F2 cohort was genotyped with three additional SSLPs on distal chromosome 1 to further analyze the suggestive BAL protein QTL on chromosome 1 identified from selective genotyping. Interval mapping of the entire F2 cohort confirmed the QTL on chromosome 1 between $101.0 \mathrm{cM}$ (D1Mit426) and $109.6 \mathrm{cM}$ (D1Mit293) (Figure $3)$. The peak likelihood $\chi^{2}$ statistic value for this QTL exceeded the threshold value of 10.0 for significant linkage as determined by 10,000 permutations with all loci from chromosome 1 only.
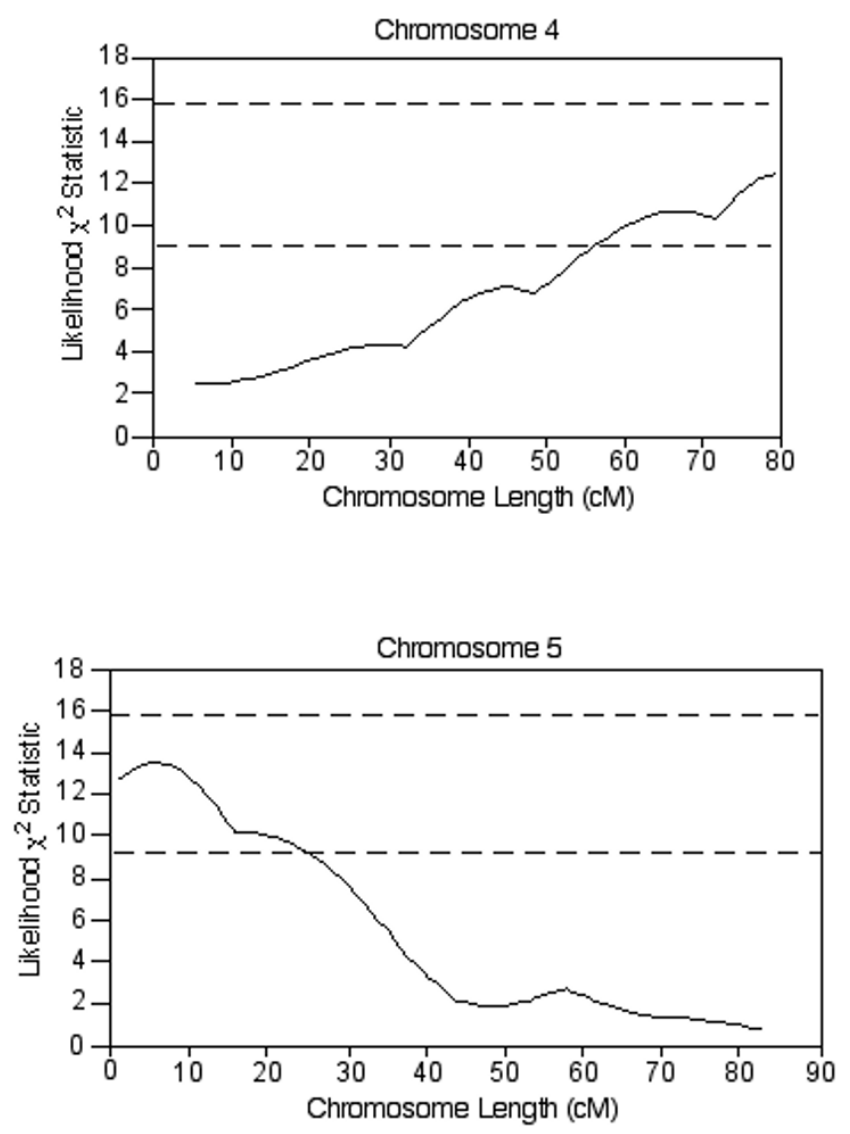

Figure 4

Plots of suggestive QTLs on chromosomes 4 and 5 associated with the BAL protein phenotype from analysis of the entire CByD2F2 cohort. The $x$-axis is the length of the chromosome in centimorgans (cM), and the $y$-axis is the likelihood $\chi^{2}$ statistic as calculated by Map Manager. The upper and lower dashed lines in each plot represent significant (LRS $=15.8$ ) and suggestive (LRS = 9.2) linkage thresholds, respectively.

The entire F2 cohort was further analyzed with the initial 86 SSLPs for the BAL protein, PMN, and macrophage phenotypes. Suggestive QTLs for the BAL protein phenotype that were not previously characterized by selective genotyping were identified on chromosome 4 between 53.6 cM (D4Mit146) and $82.5 \mathrm{cM}$ (D4Mit254), and on chromosome 5 between $1.0 \mathrm{cM}$ (D5Mit193) and $18.0 \mathrm{cM}$ (D5Mit148) (Figure 4). Suggestive QTLs for the BAL PMN and macrophages were identified on chromosomes 1 and 5, respectively (Figure 5).

\section{Haplotype analysis}

Mean BAL protein levels of F2 mice with the same haplotype were calculated and compared with the mean BAL protein levels of F2 mice with the opposite haplotype in 

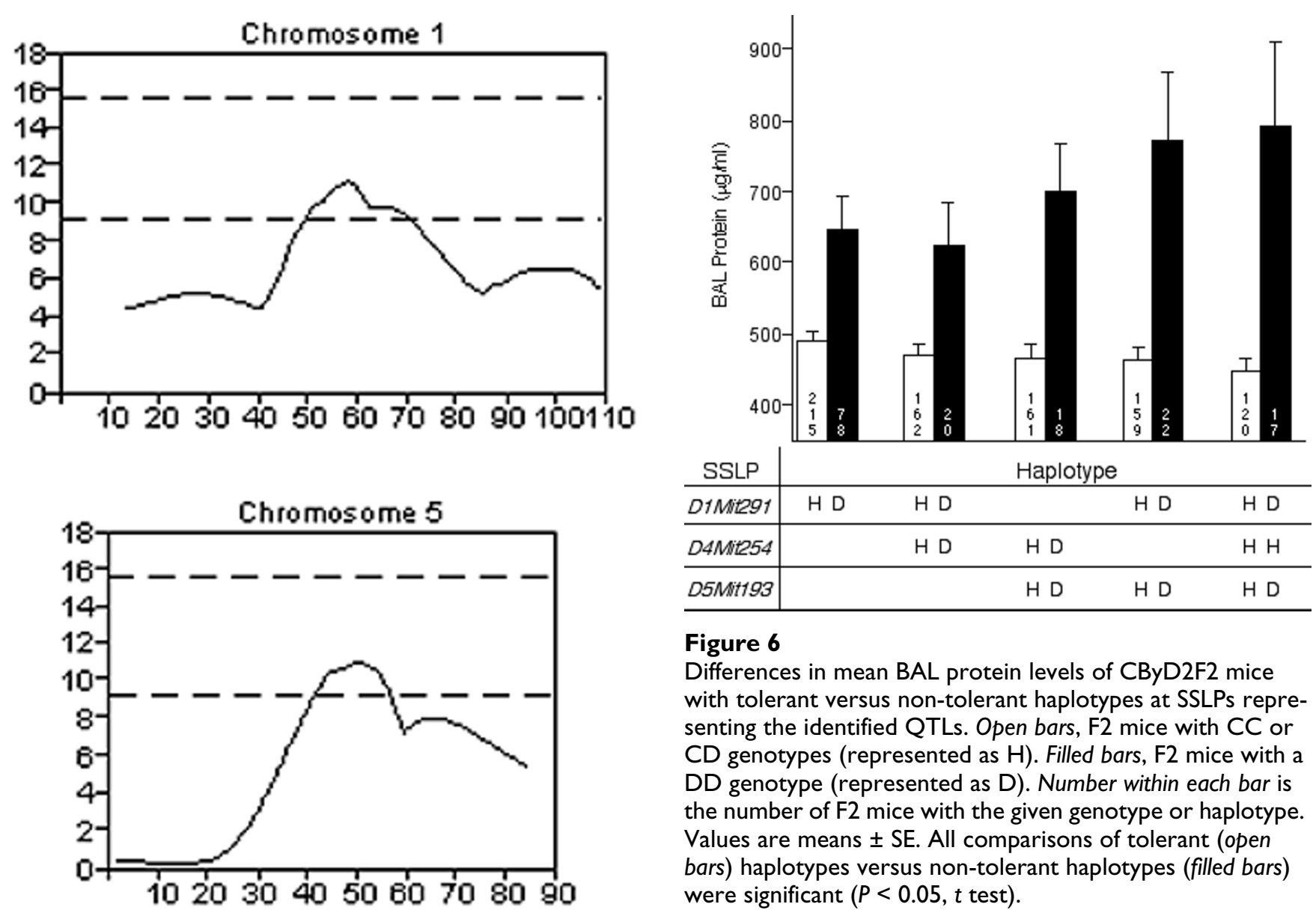

Figure 5

Plots of suggestive QTLs on chromosomes I and 5 associated with the BAL PMN and macrophage phenotypes, respectively, from analysis of the entire CByD2F2 cohort. The $x$-axis is the length of the chromosome in centimorgans (cM), and the $y$-axis is the likelihood $\chi^{2}$ statistic as calculated by Map Manager. The upper and lower dashed lines in each plot represent significant (LRS = 15.6) and suggestive (LRS = 9.2) linkage thresholds, respectively.

order to determine the contribution of each QTL and combinations of QTLs to the overall BAL protein phenotype (Figure 6). For each SSLP, F2 animals were genotyped as a homozygous CBy (CC), a homozygous D2 (DD) or heterozygous $(\mathrm{H})$. For any individual SSLP, the greatest difference in mean BAL protein was found for D1Mit291. F2 mice that were DD at that locus had an average of 156 $\mu \mathrm{g} / \mathrm{ml}$ more BAL protein than those mice that had CC or H haplotypes.

The combinatorial effect of the QTLs on chromosomes 1, 4 , and 5 were also examined. For any combination of two

QTLs, F2 mice that had a DD-DD haplotype for markers on chromosomes 1 and 5 (D1Mit291 and D5Mit193) had an average of $310 \mu \mathrm{g} / \mathrm{ml}$ more BAL protein than those that were $\mathrm{CC}$ or $\mathrm{H}(\mathrm{CC} / \mathrm{H})$ for those markers. The greatest difference in mean BAL protein levels were found in F2 mice that had a DD-CC/H-DD haplotype for the three QTLs on chromosomes 1, 4, and 5, (i.e., D1Mit291, D4Mit254, and D5Mit193), respectively. These mice had an average of $345 \mu \mathrm{g} / \mathrm{ml}$ more BAL protein than those that were $\mathrm{CC} / \mathrm{H}$ at the markers across the three chromosomes.

\section{Identification of candidate genes}

Within all of the QTLs, candidate genes discovered with potential roles in controlling the development of tolerance to inhaled $\mathrm{ZnO}$ are presented in Tables 1 and 2 . These genes were chosen as candidates from a thorough review of the existing literature and through the positional candidate gene approach, which combines knowledge of map position with the mouse transcript map [24]. 
Table I: Positional candidate genes from linkage analysis of pulmonary tolerance to BAL protein following repeated ZnO exposure.

\begin{tabular}{|c|c|c|c|c|}
\hline Chromosome & QTL Interval & Location & Human Orthology & Candidate Gene \\
\hline \multirow[t]{6}{*}{ Chr I } & $92-112 \mathrm{cM}$ & $94.0 \mathrm{cM}$ & $I(q 21-q 22)$ & Dfy, Duffy blood group \\
\hline & & $98.0 \mathrm{cM}$ & $I(q 4 I-q 42)$ & TIr5, toll-like receptor 5 \\
\hline & & $98.6 \mathrm{cM}$ & $I(q 4 I-q 42)$ & Adprt I, ADP-ribosyltransferase I \\
\hline & & $101.5 \mathrm{cM}$ & $\mathrm{I}(\mathrm{q} 4 \mathrm{I})$ & Tgfb2, transforming growth factor- $\beta 2$ \\
\hline & & $105.0 \mathrm{cM}$ & I (q32) & Traf5, TNF receptor-associated factor 5 \\
\hline & & $106.0 \mathrm{cM}$ & $I(q 32-q 4 I)$ & Slc30al, solute carrier family 30 (zinc transporter), member I \\
\hline \multirow[t]{5}{*}{ Chr 4} & $62-82 \mathrm{cM}$ & $62.4 \mathrm{cM}$ & I (p35-p34.3) & Ptafr, platelet-activating factor receptor \\
\hline & & $65.7 \mathrm{cM}$ & I (p35.3) & Slc $30 a 2$, solute carrier family 30 , member 2 \\
\hline & & $68.0 \mathrm{cM}$ & I (p35), I (p34-p36) & Pla2g2a, 2c, 2d-f, 5, phospholipase $A_{2}$ groups \\
\hline & & 75.5 & I (p36.3-p36.2), I (p36) & Tnfrsfl b, 8, 9, TNF-receptor superfamily members \\
\hline & & $79.4 \mathrm{cM}$ & I (p36) & Tnfrsf4, TNF-receptor superfamily, member 4 \\
\hline \multirow[t]{3}{*}{ Chr 5} & $\mathrm{I}-20 \mathrm{cM}$ & $14.0 \mathrm{cM}$ & $7(q 35-q 36)$ & Slc $4 a 2$, solute carrier family 4 , member 2 \\
\hline & & $17.0 \mathrm{cM}$ & $7(\mathrm{p} 2 \mathrm{I})$ & II6, interleukin 6 \\
\hline & & $18.0 \mathrm{cM}$ & 7 (pter-qter) & Slc30a3, solute carrier family 30 (zinc transporter), member 3 \\
\hline
\end{tabular}

Table 2: Positional candidate genes from linkage analysis of pulmonary tolerance to BAL PMNs and macrophages following repeated ZnO exposure.

\begin{tabular}{|c|c|c|c|c|}
\hline Chromosome & QTL Interval & Location & Human Orthology & Candidate Gene \\
\hline \multirow[t]{3}{*}{ Chr I (PMNs) } & $5 \mathrm{I}-73 \mathrm{cM}$ & $52.0 \mathrm{cM}$ & $2(q 33-q 37)$ & $\mathrm{Ccl} 20$, chemokine (C-C motif) ligand 20 \\
\hline & & $67.4 \mathrm{cM}$ & $2(q 2 I)$ & Cxcr4 chemokine (C-X-C motif) receptor 4 \\
\hline & & $69.9 \mathrm{cM}$ & $I(q 31-q 32)$ & 1110 , interleukin 10 \\
\hline \multirow{8}{*}{ Chr 5 (Macrophages) } & $43-58 \mathrm{cM}$ & $51.0 \mathrm{cM}$ & $4(q|3-q 2|)$ & Areg, amphiregulin \\
\hline & & $51.0 \mathrm{cM}$ & $4(q|3-q 2|)$ & Btc, betacellulin \\
\hline & & $51.0 \mathrm{cM}$ & $4(q 21)$ & Cxcll, chemokine (C-X-C motif) ligand I \\
\hline & & $51.0 \mathrm{cM}$ & $4(q 21)$ & $\mathrm{C} x \mathrm{Cl} 2$, chemokine ( $\mathrm{C}-\mathrm{X}-\mathrm{C}$ motif) ligand 2 \\
\hline & & $53.0 \mathrm{cM}$ & $4(q 21)$ & $\mathrm{CxCl}$, chemokine (C-X-C motif) ligand 5 \\
\hline & & $53.0 \mathrm{cM}$ & $4(q 21)$ & $\mathrm{Cxc} 19$, chemokine (C-X-C motif) ligand 9 \\
\hline & & $53.0 \mathrm{cM}$ & $4(q 21)$ & CxcllO, chemokine (C-X-C motif) ligand 10 \\
\hline & & $56.0 \mathrm{cM}$ & $4(q 21-q 25)$ & Sppl, secreted phosphoprotein I \\
\hline
\end{tabular}

\section{Development of pulmonary tolerance in MOLF/Ei mice}

We identified toll-like receptor 5 (Tlr5) as an interesting candidate gene within the significant QTL for BAL protein on chromosome 1. A wild-derived inbred mouse strain called MOLF/Ei (M. m. molossinus) which has non-conservative mutations in Tlr5 [25] was phenotyped for BAL protein following $1 \mathrm{X}$ and $5 \mathrm{X} \mathrm{ZnO}$ exposure to determine whether Tlr 5 may function in the development of pulmonary tolerance (Figure 7). MOLF/Ei BAL protein was significantly increased above control values following $1 \mathrm{X}$ $\mathrm{ZnO}$ exposure $(395 \pm 38 \mu \mathrm{g} / \mathrm{ml})$. However, MOLF/Ei mice exhibited a tolerant phenotype, as 5X BAL protein values $(215 \pm 22 \mu \mathrm{g} / \mathrm{ml})$ were significantly decreased below that of the $1 \mathrm{X}$ exposure group.

\section{Discussion}

Clinical studies on the acquisition of tolerance to inhaled toxicants suggest that genetic background and gene-environment interactions contribute to the development of pulmonary tolerance in humans. We have previously determined that a genetic component exists in a mouse model of pulmonary tolerance to repeated $\mathrm{ZnO}$ exposure [8]. In the present study, we performed linkage analyses on an F2 mouse population derived from tolerant CBy and non-tolerant D2 strains to further ascertain the contribution of genetic background to the development of pulmonary tolerance, and identify candidate genes that may be important regulators in the acquisition of tolerance. 


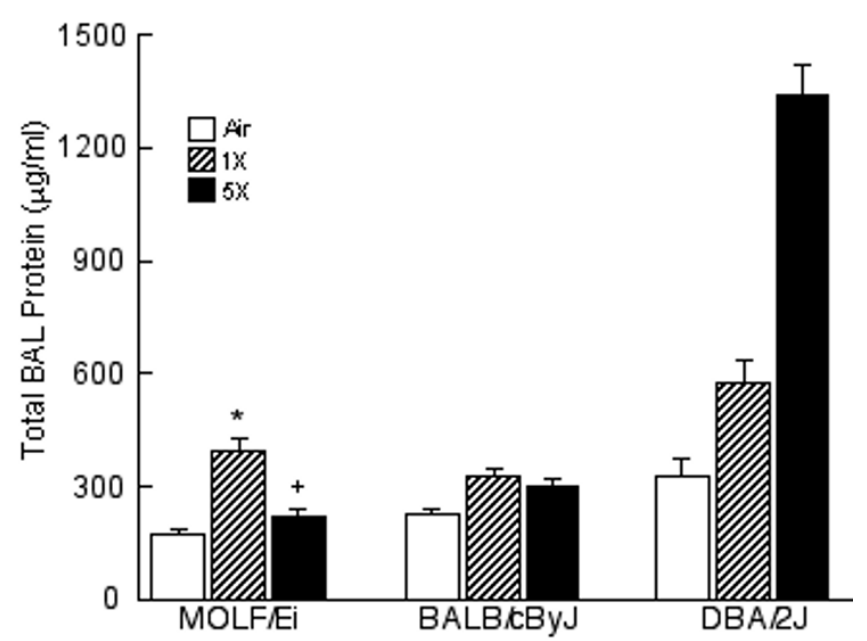

\section{Figure 7}

$\mathrm{BAL}$ protein levels in wild-derived MOLF/Ei mice $24 \mathrm{~h}$ after single (IX) or repeated (5X) exposure to $1.0 \mathrm{mg} / \mathrm{m}^{3} \mathrm{ZnO}$ or air for $3 \mathrm{~h}$. Protein levels of BALB/cByJ and DBA/2J mouse strains following $\mathrm{ZnO}$ exposure are also shown for comparison purposes. Values are means $\pm \mathrm{SE}(n=4-5 \mathrm{MOLF} / \mathrm{Ei}$ mice/exposure group). $*$ indicates significantly different from air-exposed MOLF/Ei controls, $P<0.05$ [Student-Newman Keuls (SNK) test]. + indicates significantly different from IX MOLF/Ei exposure group, $P<0.05$ (SNK test).

Initial analysis using the most tolerant and non-tolerant F2 mice with respect to BAL protein generated a putative QTL (designated as the zinc-induced tolerance $\left(Z I T_{1}\right)$ locus) on the distal end of chromosome 1. Further assessment of the entire F2 cohort demonstrated that the QTL on chromosome 1 attained an LRS value for significant linkage, and also identified two suggestive QTLs located on chromosomes 4 and 5. Using a variation of the Wright equation [17], a minimum of three loci were estimated to be independently segregating with the BAL protein phenotype following $5 \mathrm{X} \mathrm{ZnO}$ exposure, thus in agreement with the results of the linkage analysis. There are several approaches that can be pursued to focus in on the QTL intervals that were identified. For instance, increasing the number of F2 mice used in the QTL analysis is one alternative. The major disadvantage of this, however, is that segregating QTLs contribute a great deal of phenotypic "noise," making it problematic when determining whether or not a given mouse has inherited a particular QTL [9]. Thus, in order to separate the effects of multiple loci, congenic mouse strains for each QTL could be generated, which could then be used to breed multicongenic lines to examine the existence of any epistatic effects. Additionally, future studies could employ the use of a backcross (CByD2F1 × CBy) mouse population to expand the evaluation of the QTL effects to the overall BAL protein phenotype.

To measure the contribution of each individual QTL and each QTL combination to the overall BAL protein phenotype, the protein levels for F2 mice with each particular haplotype were compared. Mice with opposite allelic combinations for QTLs on chromosomes 1 and 5 had a difference of $310 \mu \mathrm{g} / \mathrm{ml}$ BAL protein, which accounts for approximately one-third of the total difference in mean BAL protein between the parental CBy and D2 strains. Additionally, the mean BAL protein level of F2 mice with a DD haplotype for QTLs on chromosomes 1, 4, and 5 was over half that of the non-tolerant D2 parental strain. These analyses suggest that although three QTLs were identified, the development of pulmonary tolerance to BAL protein is a decidedly complex phenotype that is regulated by a number of different genes, some of which were likely not identified by linkage analysis using an F2 cohort.

Candidate genes within the significant QTL on chromosome $1\left(Z I T_{1}\right)$ that could play a role in controlling the development of tolerance to BAL protein following repeated $\mathrm{ZnO}$ exposure are presented in Table 1. The Duffy blood group ( $D f y$ ) has been shown to modulate the intensity of inflammation following endotoxin exposure [26], and has a role in enhancing inflammatory cell recruitment to sites of inflammation by facilitating movement of chemokines across the endothelium [27]. ADPribosyltransferase 1 (Adprt1) and tumor necrosis factor (TNF) receptor-associated factor (Traf5) are functionally associated with nuclear factor $(\mathrm{NF})-\kappa \mathrm{B}$, a key transcription factor in the regulation of the inflammatory process $[28,29]$. Additionally, activation of ADPRT1 plays a role in endotoxin-induced BAL protein increases [30,31]. Activated transforming growth factor- $\beta$ has been shown to be a mediator of bleomycin- and endotoxin-induced lung permeability (i.e., BAL protein) in mice [32]. Finally, solute carrier family 30 (zinc transporter), member 1 (Slc30a1) is a metal transporter on the plasma membrane that confers resistance to zinc and cadmium toxicity in vitro via an efflux mechanism [33,34].

Candidate genes for BAL protein tolerance identified within the suggestive QTL intervals on chromosomes 4 and 5 are also presented in Table 1. Notable candidates include platelet-activating factor receptor (Ptafr) and phospholipase $\mathrm{A}_{2}$ (Pla2) that have been implicated as potential mediators of toxicant-induced BAL protein increases [35-37]. Interleukin (IL)-6 protein was increased following $\mathrm{ZnO}$ exposure in humans [1,38], and was hypothesized to be an anti-inflammatory suppressor of $\mathrm{ZnO}$-induced lung injury. Interestingly, increased lung IL6 levels have been shown to mediate pulmonary tolerance 
to ozone in rats [39]. Lastly, solute carrier family 30 (zinc transporter) members 2 and 3 (Slc30a2 and Slc30a3) have been identified as zinc transporters that protect against zinc-induced toxicity in both cell culture and animal models $[40,41]$. The development of pulmonary tolerance to BAL protein in our model could be regulated by any number of the aforementioned candidate genes. These candidates will be investigated in future studies of transcriptional and protein regulation to determine their roles in the development of tolerance.

The suggestive QTLs for tolerance to BAL PMNs and macrophages (on chromosomes 1 and 5, respectively) were also examined for positional candidate genes (Table 2). Chemokine (C-C motif) ligand 20 (Ccl20), chemokine (C-X-C motif) receptor 4 (Cxcr4), and interleukin-10 (Il10) were identified as candidates for BAL PMN tolerance. The movement of PMNs into inflammatory tissues is regulated by chemotactic factors (e.g., chemokines) that signal through numerous chemokine receptors [42]. PMNs are capable of producing several chemokines and proinflammatory cytokines, indicating that PMNs may be important in auto-direction of cell trafficking during inflammation. CXCR4 expression has been detected on human PMNs [43], and coordinated chemokine receptor gene expression may control the tissue-specific migration and activation status of PMNs into the lung. Human PMNs are also able to express CCL20 [44], which is able to recruit immature dendritic cells that play an important role in the initiation of the immune response as well as chronic inflammation [45-47]. Finally, IL-10 can be produced by $\mathrm{T}$ cells and is able to diminish PMN influx by inhibition of expression of proinflammatory chemokines [48], NF-KB (via I kappa kinase) [49], and TNF [50], as well as modulate cells and effector functions associated with an allergic response. With respect to the BAL macrophage phenotype, the epidermal growth factor receptor (EGFR) ligands amphiregulin (Areg) and betacellulin $(B t c)$ were identified as candidate genes within the suggestive QTL on chromosome 5. Ligand-dependent activation of the EGFR by particles rich in metal content lead to activation of the MAP kinase signaling cascade and cytokine expression and secretion [51,52]. Secreted phosphoprotein 1 (Spp1, also known as osteopontin) was also identified, and it can act as a chemoattractant for macrophages $[53,54]$. Lastly, a host of chemokine (C-X-C motif) ligands were identified between 51 and $53 \mathrm{cM}$ that could be involved in macrophage chemotaxis [55]. Again, tolerance to BAL PMNs and macrophages may be under the influence of any number of these candidate genes.

In the present study, we identified toll-like receptor (Tlr5) as a candidate gene within the significant $Z \mathrm{ZT}_{1}$ QTL on chromosome 1 for tolerance to BAL protein. Toll-like receptors activate intra-cellular signaling that culminates in the induction of a multitude of effector genes [56]. Tlr5 has been shown to be an important gene in the immune response to Gram-positive and Gram-negative bacterial flagellin $[57,58]$. We utilized a wild-derived inbred mouse strain called MOLF/Ei which has non-conservative mutations in Tlr5 that are associated with a lower level of expression [25] to determine whether Tir5 plays a role in the development of tolerance to BAL protein in our $\mathrm{ZnO}$ model. Because MOLF/Ei mice have a lower level of TLR5 mRNA expression compared to other strains [25], it was unclear whether we would observe tolerance after a single exposure to $\mathrm{ZnO}$. Although the MOLF/Ei strain has no "wild-type" control strain per se, MOLF/Ei mice were tolerant to increased BAL protein following repeated $\mathrm{ZnO}$ exposure when compared to the non-tolerant D2 strain. These data support a role for Tir5 in the development of tolerance to BAL protein. Interestingly, Kleeberger and colleagues identified Tlr4 as a candidate gene in a study of susceptibility to increased BAL protein in mice following a single exposure to $0.3 \mathrm{ppm}$ ozone for 72 hours [22], which also suggests toll-like receptor signaling may be important in the regulation of inhaled toxicant-induced changes in BAL protein.

The mechanism through which Tlr5 signaling may regulate the development of tolerance to $\mathrm{ZnO}$ is unknown. While endotoxin [59] and bacterial flagellin [60] have been demonstrated as the primary ligands for Tlr4 and Tlr5, respectively, the ligand(s) that is responsible for tolllike receptor signaling following exposure to inhaled toxicants such as ozone and $\mathrm{ZnO}$ is unknown. Although there have been no studies on endogenous ligands for Tlr5, several endogenous ligands for Tlr4 have been identified. For example, fibronectin [61] and hyaluronic acid [62] are produced by lung cells during lung injury and are endogenous Tlr4 ligands. The downstream pathway through which Tlr5 may regulate the development of tolerance to $\mathrm{ZnO}$-induced BAL protein is potentially via NF$\kappa \mathrm{B}$, a transcription factor that is known to induce several cytokines involved in inhaled $\mathrm{ZnO}$ responsiveness such as IL-8 and IL-6 $[1,63]$. Furthermore, NF- $\mathrm{kB}-$ dependent gene expression is decreased in Tlr5-mediated tolerance to flagellin in vitro [64]. Thus, it is plausible that a mutation in Tlr5, a regulatory element upstream of NF- $\mathrm{\kappa B}$ signaling, could modulate tolerance to BAL protein from repeated $\mathrm{ZnO}$ exposure. Finally, Tlr 5 may function as a danger signal receptor in the development of $\mathrm{ZnO}$ tolerance, consistent with the "danger model" of innate immunity that explicates activation of the innate immune system by factors other than foreign antigens [65]. Whatever the case, much work is needed in understanding how toxicants function through toll-like receptor signaling mechanisms in the lung to regulate adverse responses such as BAL protein. 
In summary, linkage analysis of a large F2 mouse cohort identified significant linkage of a QTL $\left(Z I T_{1}\right)$ on chromosome 1 associated with tolerance to BAL protein following repeated exposure to inhaled $\mathrm{ZnO}$. Suggestive QTLs were also identified on chromosomes 4 and 5 for BAL protein, on chromosome 1 for BAL PMNs, and on chromosome 5 for BAL macrophages. Haplotype analysis suggested that the combinatorial effects of these three loci contributed to the overall phenotype, which agrees with the calculated number of segregating loci. Tlr5 was identified within the significant QTL for BAL protein on chromosome 1. Wildderived Tlr5-mutant MOLF/Ei mice were determined to be tolerant to BAL protein following repeated $\mathrm{ZnO}$ exposure, suggesting a role for Tlr5 in the development of pulmonary tolerance to inhaled toxicants.

\section{Conclusion}

These data substantiate genetic background as an important influence in the acquisition of pulmonary tolerance following exposure to inhaled toxicants such as $\mathrm{ZnO}$, and promising candidate genes exist within the identified QTL intervals that would be good targets for additional studies on the pathogenesis of tolerance.

\section{Competing interests}

The author(s) declare that they have no competing interests.

\section{Authors' contributions}

SCW: Participated in the design and coordination of the study, performed the study, and drafted the manuscript.

LCC: Participated in the design of the study and helped draft the manuscript.

TG: Conceived the study, participated in the design and coordination of the study, and helped draft the manuscript.

\section{Acknowledgements}

The authors would like to thank the following people for their contributions to this study: Karen Galdanes, Margaret Krasinski, Kathy Baker, and Dr. Moon-shong Tang (New York University); Dr. George D. Leikauf (University of Cincinnati); Dr. Daniel R. Prows (Cincinnati Children's Hospital); Dr. Steven R. Kleeberger (National Institute of Environmental Health Sciences); Dr. Carrie L. Welch (Columbia University). This study was supported by USEPA Grant R-826244, USEPA Particulate Matter Center Grant R-82735I, USEPA STAR Fellowship U-9157830I, NIEHS Center Grant of Excellence ES-00260, and CDC/NIOSH (via Mt. Sinai School of Medicine, New York, NY) Grant T-42CCT210425-06-0I.

\section{References}

I. Fine JM, Gordon T, Chen LC, Kinney P, Falcone G, Beckett WS: Metal fume fever: characterization of clinical and plasma IL6 responses in controlled human exposures to zinc oxide fume at and below the threshold limit value. J Occup Environ Med 1997, 39:722-726.
2. Kline JN, Cowden JD, Hunninghake GW, Schutte BC, Watt JL, Wohlford-Lenane CL, Powers LS, Jones MP, Schwartz DA: Variable airway responsiveness to inhaled lipopolysaccharide. Am J Respir Crit Care Med 1999, 160:297-303.

3. Christian DL, Chen LL, Scannell CH, Ferrando RE, Welch BS, Balmes JR: Ozone-induced inflammation is attenuated with multiday exposure. Am J Respir Crit Care Med I998, I 58:532-537.

4. Jorres RA, Holz O, Zachgo W, Timm P, Koschyk S, Muller B, Grimminger F, Seeger W, Kelly FJ, Dunster C, Frischer T, Lubec G, Waschewski M, Niendorf A, Magnussen $\mathrm{H}$ : The effect of repeated ozone exposures on inflammatory markers in bronchoalveolar lavage fluid and mucosal biopsies. Am J Respir Crit Care Med 2000, I 6 I:1855-1861.

5. Horvath SM, Gliner JA, Folinsbee LJ: Adaptation to ozone: duration of effect. Am Rev Respir Dis 198I, I 23:496-499.

6. Hackney JD, Linn WS, Mohler JG, Collier CR: Adaptation to shortterm respiratory effects of ozone in men exposed repeatedly. J Appl Physiol 1977, 43:82-85.

7. Wesselkamper SC, Chen LC, Gordon T: Development of pulmonary tolerance in mice exposed to zinc oxide fumes. Toxicol Sci 2001, 60:144-151.

8. Wesselkamper SC, Chen LC, Kleeberger SR, Gordon T: Genetic variability in the development of pulmonary tolerance to inhaled pollutants in inbred mice. Am J Physiol Lung Cell Mol Physiol 200I, 28I:LI200-9.

9. Silver LM: Mouse genetics: concepts and applications. New York, Oxford University Press; 1995.

10. Cho HY, Jedlicka AE, Reddy SP, Zhang LY, Kensler TW, Kleeberger SR: Linkage analysis of susceptibility to hyperoxia. Nrf2 is a candidate gene. Am J Respir Cell Mol Biol 2002, 26:42-5I.

II. Kleeberger SR, Levitt RC, Zhang LY, Longphre M, Harkema J, Jedlicka $A$, Eleff SM, DiSilvestre D, Holroyd KJ: Linkage analysis of susceptibility to ozone-induced lung inflammation in inbred mice. Nat Genet 1997, 17:475-478.

12. Prows DR, Shertzer HG, Daly MJ, Sidman CL, Leikauf GD: Genetic analysis of ozone-induced acute lung injury in sensitive and resistant strains of mice. Nat Genet 1997, 1 7:47| -474.

13. Kleeberger SR, Reddy SP, Zhang LY, Cho HY, Jedlicka AE: Toll-like receptor 4 mediates ozone-induced murine lung hyperpermeability via inducible nitric oxide synthase. Am J Physiol Lung Cell Mol Physiol 200I, 280:L326-33.

14. Ohtsuka Y, Brunson KJ, Jedlicka AE, Mitzner W, Clarke RW, Zhang LY, Eleff SM, Kleeberger SR: Genetic linkage analysis of susceptibility to particle exposure in mice. Am J Respir Cell Mol Biol 2000, 22:574-58I.

15. Prows DR, Leikauf GD: Quantitative trait analysis of nickelinduced acute lung injury in mice. Am J Respir Cell Mol Biol 200I, 24:740-746.

16. McCarthy JF, Yurek GJ, Elliott JF, Amdur MO: Generation and characterization of submicron aerosols of zinc oxide. Am Ind Hyg Assoc J 1982, 880-886:.

17. Wright S: The genetics of quantitative variability. In Quantitave Genetics Edited by: Reeve ECH and Waddington $\mathrm{CH}$. London, HMSO; 1952.

18. Manly KF, Olson JM: Overview of QTL mapping software and introduction to map manager QT. Mamm Genome 1999 , I 0:327-334.

19. Churchill GA, Doerge RW: Empirical threshold values for quantitative trait mapping. Genetics 1994, I38:963-97I.

20. Doerge RW, Churchill GA: Permutation tests for multiple loci affecting a quantitative character. Genetics 1996, 142:285-294.

21. Lander ES, Botstein D: Mapping mendelian factors underlying quantitative traits using RFLP linkage maps. Genetics 1989 , I21:185-199.

22. Kleeberger SR, Reddy S, Zhang LY, Jedlicka AE: Genetic susceptibility to ozone-induced lung hyperpermeability: role of tolllike receptor 4. Am J Respir Cell Mol Biol 2000, 22:620-627.

23. Lander E, Kruglyak L: Genetic dissection of complex traits: guidelines for interpreting and reporting linkage results. Nat Genet 1995, I I:241-247.

24. Collins FS: Positional cloning moves from perditional to traditional. Nat Genet 1995, 9:347-350.

25. Sebastiani G, Leveque G, Lariviere L, Laroche L, Skamene E, Gros P, Malo D: Cloning and characterization of the murine toll-like receptor 5 (TIr5) gene: sequence and mRNA expression 
studies in Salmonella-susceptible MOLF/Ei mice. Genomics 2000, 64:230-240.

26. Dawson TC, Lentsch AB, Wang Z, Cowhig JE, Rot A, Maeda N, Peiper SC: Exaggerated response to endotoxin in mice lacking the Duffy antigen/receptor for chemokines (DARC). Blood 2000, 96:168I-1684.

27. Lee JS, Frevert CW, Wurfel MM, Peiper SC, Wong VA, Ballman KK, Ruzinski JT, Rhim JS, Martin TR, Goodman RB: Duffy antigen facilitates movement of chemokine across the endothelium in vitro and promotes neutrophil transmigration in vitro and in vivo. J Immunol 2003, 170:5244-525I.

28. Hassa PO, Hottiger MO: A role of poly (ADP-ribose) polymerase in NF-kappaB transcriptional activation. Biol Chem 1999, 380:953-959.

29. Nakano H, Oshima H, Chung W, Williams-Abbott L, Ware CF, Yagita $\mathrm{H}$, Okumura K: TRAF5, an activator of NF-kappaB and putative signal transducer for the lymphotoxin-beta receptor. J Biol Chem 1996, 27 I: | 466|- 4664.

30. Albertini M, Clement MG, Lafortuna CL, Caniatti M, Magder S, Abdulmalek K, Hussain SN: Role of poly-(ADP-ribose) synthetase in lipopolysaccharide-induced vascular failure and acute lung injury in pigs. J Crit Care 2000, 15:73-83.

31. Liaudet L, Pacher P, Mabley JG, Virag L, Soriano FG, Hasko G, Szabo C: Activation of poly(ADP-Ribose) polymerase- $I$ is a central mechanism of lipopolysaccharide-induced acute lung inflammation. Am J Respir Crit Care Med 2002, 165:372-377.

32. Pittet JF, Griffiths MJ, Geiser T, Kaminski N, Dalton SL, Huang X, Brown LA, Gotwals PJ, Koteliansky VE, Matthay MA, Sheppard D: TGF-beta is a critical mediator of acute lung injury. J Clin Invest 2001, 107:1537-1544.

33. Kim AH, Sheline CT, Tian M, Higashi T, McMahon RJ, Cousins RJ, Choi DW: L-type $\mathbf{C a}(2+)$ channel-mediated $\mathrm{Zn}(2+)$ toxicity and modulation by $\mathrm{ZnT}-\mathrm{I}$ in PCI 2 cells. Brain Res 2000, 886:99-107.

34. Palmiter RD, Findley SD: Cloning and functional characterization of a mammalian zinc transporter that confers resistance to zinc. Embo J 1995, | 4:639-649.

35. Furue S, Kuwabara K, Mikawa K, Nishina K, Shiga M, Maekawa N, Ueno M, Chikazawa Y, Ono T, Hori Y, Matsukawa A, Yoshinaga M, Obara H: Crucial role of group IIA phospholipase $\mathbf{A}(2)$ in oleic acid-induced acute lung injury in rabbits. Am J Respir Crit Care Med 1999, 160:1292-1302.

36. Kaneko T, lkeda H, Fu L, Nishiyama H, Okubo T: Platelet-activating factor mediates the ozone-induced increase in airway microvascular leakage in guinea pigs. Eur J Pharmacol 1995, 292:25I-255.

37. Longphre M, Zhang L, Harkema JR, Kleeberger SR: Ozone-induced pulmonary inflammation and epithelial proliferation are partially mediated by PAF. J Appl Physiol 1999, 86:34I-349.

38. Fine JM, Gordon T, Chen LC, Kinney P, Falcone G, Sparer J, Beckett WS: Characterization of clinical tolerance to inhaled zinc oxide in naive subjects and sheet metal workers. J Occup Environ Med 2000, 42: 1085-109I.

39. McKinney WJ, Jaskot RH, Richards JH, Costa DL, Dreher KL: Cytokine mediation of ozone-induced pulmonary adaptation. Am J Respir Cell Mol Biol 1998, 18:696-705.

40. Palmiter RD, Cole TB, Findley SD: ZnT-2, a mammalian protein that confers resistance to zinc by facilitating vesicular sequestration. Embo J 1996, I5:|784-|79|

41. Palmiter RD, Cole TB, Quaife CJ, Findley SD: ZnT-3, a putative transporter of zinc into synaptic vesicles. Proc Natl Acad Sci U S A 1996, 93: | 4934-| 4939.

42. Baggiolini M: Chemokines and leukocyte traffic. Nature 1998, 392:565-568.

43. Yousefi S, Cooper PR, Potter SL, Mueck B, Jarai G: Cloning and expression analysis of a novel G-protein-coupled receptor selectively expressed on granulocytes. J Leukoc Biol 200I, 69:1045-1052.

44. Scapini P, Laudanna C, Pinardi C, Allavena P, Mantovani A, Sozzani S, Cassatella MA: Neutrophils produce biologically active macrophage inflammatory protein-3alpha (MIP-3alpha)/CCL20 and MIP-3beta/CCLI 9. Eur J Immunol 200I, 31:1981-1988.

45. Dieu-Nosjean MC, Vicari A, Lebecque S, Caux C: Regulation of dendritic cell trafficking: a process that involves the participation of selective chemokines. J Leukoc Biol 1999, 66:252-262.
46. Dieu-Nosjean MC, Massacrier C, Homey B, Vanbervliet B, Pin J, Vicari A, Lebecque S, Dezutter-Dambuyant C, Schmitt D, Zlotnik A, Caux C: Macrophage inflammatory protein 3alpha is expressed at inflamed epithelial surfaces and is the most potent chemokine known in attracting Langerhans cell precursors. J Exp Med 2000, I 92:705-7I8.

47. Sallusto $F$, Lanzavecchia A: Mobilizing dendritic cells for tolerance, priming, and chronic inflammation. J Exp Med 1999, | 89:6||-6|4

48. Shanley TP, Vasi N, Denenberg A: Regulation of chemokine expression by IL-10 in lung inflammation. Cytokine 2000, 12:1054-1064.

49. Spight D, Zhao B, Haas M, Wert S, Denenberg A, Shanley TP: Immunoregulatory effects of regulated, lung-targeted expression of IL- 10 in vivo. Am J Physiol Lung Cell Mol Physiol 2005, 288:L25 I-65.

50. Mulligan MS, Warner RL, Foreback JL, Shanley TP, Ward PA: Protective effects of IL-4, IL-10, IL-I2, and IL-I3 in IgG immune complex-induced lung injury: role of endogenous IL-I 2 . J Immunol 1997, I 59:3483-3489.

51. Wu W, Samet JM, Ghio AJ, Devlin RB: Activation of the EGF receptor signaling pathway in airway epithelial cells exposed to Utah Valley PM. Am J Physiol Lung Cell Mol Physiol 200I, 28I:L483-9.

52. Blanchet S, Ramgolam K, Baulig A, Marano F, Baeza-Squiban A: Fine particulate matter induces amphiregulin secretion by bronchial epithelial cells. Am J Respir Cell Mol Biol 2004, 30:42 I-427.

53. O'Regan AW, Hayden JM, Body S, Liaw L, Mulligan N, Goetschkes M, Berman JS: Abnormal pulmonary granuloma formation in osteopontin-deficient mice. Am J Respir Crit Care Med 200I, 164:2243-2247.

54. Ophascharoensuk V, Giachelli CM, Gordon K, Hughes J, Pichler R, Brown P, Liaw L, Schmidt R, Shankland SJ, Alpers CE, Couser WG, Johnson RJ: Obstructive uropathy in the mouse: role of osteopontin in interstitial fibrosis and apoptosis. Kidney Int 1999, 56:57I-580

55. Driscoll KE: Macrophage inflammatory proteins: biology and role in pulmonary inflammation. Exp Lung Res 1994, 20:473-490.

56. Kopp EB, Medzhitov R: The Toll-receptor family and control of innate immunity. Curr Opin Immunol 1999, II:I3-18.

57. Hayashi F, Smith KD, Ozinsky A, Hawn TR, Yi EC, Goodlett DR, Eng JK, Akira S, Underhill DM, Aderem A: The innate immune response to bacterial flagellin is mediated by Toll-like receptor 5. Nature 2001, 41 0:1099-1103.

58. Gewirtz AT, Navas TA, Lyons S, Godowski PJ, Madara JL: Cutting edge: bacterial flagellin activates basolaterally expressed TLR5 to induce epithelial proinflammatory gene expression. J Immunol 200I, 167:1882-1885.

59. Lien E, Means TK, Heine H, Yoshimura A, Kusumoto S, Fukase K, Fenton MJ, Oikawa M, Qureshi N, Monks B, Finberg RW, Ingalls RR, Golenbock DT: Toll-like receptor 4 imparts ligand-specific recognition of bacterial lipopolysaccharide. J Clin Invest 2000, 105:497-504.

60. Donnelly MA, Steiner TS: Two nonadjacent regions in enteroaggregative Escherichia coli flagellin are required for activation of toll-like receptor 5. J Biol Chem 2002, 277:40456-4046I.

61. Okamura Y, Watari M, Jerud ES, Young DW, Ishizaka ST, Rose J, Chow JC, Strauss JF: The extra domain $\mathbf{A}$ of fibronectin activates Toll-like receptor 4. J Biol Chem 200I, 276: 10229-10233.

62. Taylor KR, Trowbridge JM, Rudisill JA, Termeer CC, Simon JC, Gallo $\mathrm{RL}$ : Hyaluronan fragments stimulate endothelial recognition of injury through TLR4. J Biol Chem 2004, 279: I 7079-17084.

63. Kuschner WG, D'Alessandro A, Wong H, Blanc PD: Early pulmonary cytokine responses to zinc oxide fume inhalation. Environ Res 1997, 75:7-II.

64. Mizel SB, Snipes JA: Gram-negative flagellin-induced self-tolerance is associated with a block in interleukin-I receptorassociated kinase release from toll-like receptor 5 . J Biol Chem 2002, 277:224I4-22420.

65. Matzinger P: The danger model: a renewed sense of self. Science 2002, 296:30I-305. 